\title{
Absorption-desorption of carbon dioxide in carbon honeycombs at elevated temperatures
}

\author{
Nina V. Krainyukova ${ }^{1}$, Yuri Bogdanov ${ }^{1,2}$, and Bogdan Kuchta ${ }^{3,4}$ \\ ${ }^{I}$ B. Verkin Institute for Low Temperature Physics and Engineering of the National Academy of Sciences of Ukraine \\ 47 Nauky Ave., Kharkiv 61103, Ukraine \\ E-mail: krainyukova@ilt.kharkov.ua \\ ${ }^{2}$ National Technical University “Kharkiv Polytechnical Institute”, 2 Kyrpychova Str., Kharkiv 61002, Ukraine \\ ${ }^{3}$ Université Aix-Marseille, CNRS, MADIREL, Marseille 13396, France \\ ${ }^{4}$ Department of Physics and Astronomy, University of Missouri, Columbia MO, USA
}

Received October 24, 2018

\begin{abstract}
The recently synthesized honeycomb carbon allotrope has numerous potential applications, in particular for storage of gases inside carbon matrices. In this work this carbon form was experimentally studied in its denser form in order to estimate the upper temperature limit for keeping a gas inside the cellular structure. Along with the previously reported random honeycombs of a zigzag type we have also revealed the densest armchair structure. The mechanism of absorption-desorption of carbon dioxide studied by means of high energy electron diffraction at low temperatures showed the two - stage character of the observed desorption at elevated temperatures. This effect is associated to the weaker or stronger bonding of molecules with pore walls depending on the specific configuration of channels with different sizes. We have found that complete desorption of $\mathrm{CO}_{2}$ does not occur even at the temperatures about three times higher as compared with the sublimation point of carbon dioxide in our vacuum conditions.
\end{abstract}

Keywords: high-energy electron diffraction, gas absorption, carbon honeycombs.

\section{Introduction}

Many carbon allotropes such as fullerenes [1], nanotubes [2,3], peapods [4], "schwarzite" forms [5-7], carbon nanowires [8], graphene [9] were discovered and intensively studied during the last few decades. The carbon-based materials possess many potential applications in modern and future technologies. Special attention was focused on investigations [10-13] of light molecules absorption in nanoporous materials. This process is used in technological applications such as reduction of carbon dioxide emissions by vehicles, molecular sieving or fuel cells. In spite of high potential of hydrogen as a fuel, i.e., as a renewable and environmentally friendly energy source, its application is limited by the lack of simultaneously lightweight and efficient storage volumes with the high gravimetric ratio between the weight of absorbed hydrogen and the total weight of the system.

The recently synthesized carbon honeycomb structure [14] is an exceptionally stable carbon allotrope. Absorption of the heavier rare gases such as krypton and xenon in carbon films obtained by deposition of vacuum sublimated graphite was studied a few years earlier [15]. It was found in particular that the levels of gas absorption attain $4-6 \%$ in atomic count with respect to the number of carbon atoms in such substrates. This is about twice higher as compared with even theoretical values attainable in carbon nanotubes $[16,17]$. However, the carbon honeycomb structure was identified only when transmission electron microscopy and the exhaustive structural analysis were applied [14]. Many interesting details of these structures still require much higher resolution technique.

In this work we study absorption with consequent desorption of carbon dioxide in the denser carbon honeycomb aiming to find the upper temperature limit for gas desorption from this structure.

\section{Carbon film preparation}

As it was reported previously $[14,18]$, in quest of lowdensity carbon structures with numerous channels accessi- 


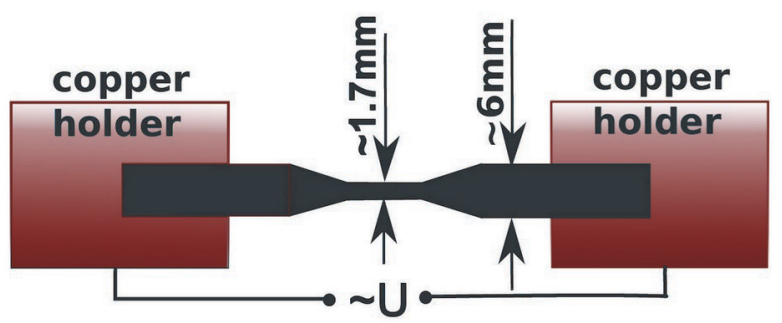

Fig. 1. The scheme of carbon sublimation from the graphitic rods used for the carbon film preparation.

ble for gas absorption, we switched from the arc discharge to pure sublimation of graphite rods thinned in their central parts and heated by the electric current (Fig. 1).

In this method we allow only sublimation when the weaker bonds between graphitic layers are destroyed while $s p^{2}$ links inside graphene-like planes are still preserved. In this way we obtain graphene patches with tightly bonded $s p^{2}$ network. They can easily fly in vacuum and, according to the theoretical prediction [19], may collide with previously deposited flat fragments in a way that they form right or big enough angles with other patches which result in formation of junction structures. Besides the small patches tend to close dangling bonds at their edges that make the "big angle" deposition with collision energetically more favorable. For these reasons the parallel deposition probability is negligible in the total angle distribution. These junction structures called in [14] "carbon honeycomb" (hc) are different from those of common graphitic materials. In carbon honeycombs two "wall-chiralities" (armchair — hcA and zigzag - hcZ) may be formed, and the structures with various widths of walls and therefore different densities of such carbon materials can be synthesized [14,18-24].

In our preparation we varied the electric current between 65 and $85 \mathrm{~A}$ to choose the regime when denser films form. In this way we expected to obtain the stronger bonding of the absorbed gas with cell walls and to estimate the upper temperature limit for keeping the gas inside the carbon honeycomb matrices.

Carbon films were deposited on cleaved single crystal surface of $\mathrm{NaCl}$ and further were separated from salt by means of floating in distilled water. Such films then were put onto the copper grids with a cell size about $0.1 \mathrm{~mm}$ transparent for electrons and were placed on the holder inside the column of the diffraction setup.

\section{Experimental}

According to our previous findings the high absorption ability of carbon films prepared by the method described above and in more detail in [18] can be attained if a gas (e.g., gaseous carbon dioxide) is first deposited on carbon substrates inside the low-temperature cryostat well below the sublimation points of polycrystalline films $\left(T_{\text {subl }} \sim 86 \mathrm{~K}\right.$ for considered $\mathrm{CO}_{2}$ ). The studies are performed with the help of the high energy electron diffraction setup EMR100 supplied with the low-temperature cryostat. After deposition good quality thin solid polycrystalline films with distinct diffraction peaks formed. But when they are gradually heated and kept slightly below the characteristic sublimation points, the strong diffraction peaks corresponding to a polycrystalline state disappear, but distinct residual signals remain. These residual signals are still observed at temperatures far above the sublimation points owing to physical absorption of gases with strong bonding in a carbon matrix. We ascribe these features to specificity of composites formed from the gaseous phase when gas atoms are strongly bonded inside carbon matrices after capillary filling at temperatures slightly below the sublimation points. In our current experiment with $\mathrm{CO}_{2}$ the deposition temperature $\sim 80 \mathrm{~K}$ was closer to the sublimation point and we observed the absorption effect already during deposition.

\section{The analysis method}

The carbon films produced by the method described above as well as composites based on carbon structures filled with absorbed gases were studied by means of Transmission High-Energy Electron Diffraction (THEED) in an EMR-100 electron diffraction setup. These studies were supported by the advanced analysis of the obtained data [25].

In the precise analysis of diffraction patterns from carbon films (see the next section) the experimental intensities $I_{\text {exp }}(S)$ are compared with calculated values

$$
I_{\text {calc }}(S)=\exp \left(-\left\langle u^{2}\right\rangle S\right)^{2} f^{2}\left[\frac{1}{(1-t)}+\sum_{k} w_{k} I_{\text {calc }, k}(S)\right] \text {, }
$$

here $\left\langle u^{2}\right\rangle$ are the mean-square atomic displacements, $f$ is the atomic scattering factor for electrons, $w_{k}$ are the varied probabilities of the presence of a structural fragment $k$ comprised of $N_{k}$ atoms and

$$
I_{\text {calc }, k}(S)=\frac{2}{N_{k}}\left[\sum_{m>n} \frac{\sin \left(S r_{m n}\right)}{S r_{m n}}\right]_{k}
$$

is the Debye formula [26]. Here $r_{\mathrm{mn}}$ is a distance between a pair of atoms in a structural fragment $k$ and $\sum_{k} w_{k}=1$. The value $t$ (in contrast with isolated clusters [27]) characterizes a fraction of atoms belonging to different fragments whose oscillating terms with $I_{\text {calc }, k}(S)$ (Eq. (2)) mutually cancel each other in $I_{\text {calc }}(S)$ (Eq. (1)) giving a contribution only in the monotonic term $\sim f^{2}$. The electron diffraction intensities $I_{\exp }$ are the functions of the scattering wave vector $S=4 \pi \sin \theta / \lambda$. Here, $2 \theta$ is the scattering angle, and $\lambda$ is the de Broglie wavelength of the electrons.

The calculated diffraction intensities are compared with experiment by means of minimization of the reliability factor 


$$
R=\frac{\sum_{S}\left|I_{\exp }-I_{\text {calc }}\right|}{\sum_{S}\left(I_{\exp }+I_{\text {calc }}\right)},
$$

with respect to $w_{k}$, here the summation over $S$ is performed with the step $0.02 \AA^{-1}$.

\section{The structure of carbon films}

We tested previously $[14,18]$ numerous structural components including graphite, fullerenes, schwarzites, nanotubes in order to describe the $S$ dependences of the diffraction intensities $I_{\text {exp }}(S)$ from carbon films. We have found in particular very limited contribution of differently sized graphite fragments with their total amount not exceeding $\sim 10 \%$ that is also confirmed in the presented study. Carbon nanotubes, whose probable appearance in our samples could owe to the symbiosis with the carbon honeycomb structures [14] have overall contribution $w_{k}$ as a rule not exceeding 3-4\%. The carbon honeycomb structures in majority prevailed under the proposed preparation conditions. For this reason in the study described here we used only honeycomb structures with addition of small pieces of graphitic carbon for evaluation of its probable contribution. The carbon honeycomb is not a single structure but is a family of structures. The honeycomb hexagon side sizes are $a_{0}=(2.5+1.5 n) r_{N N}$ for a zigzag type structure; here

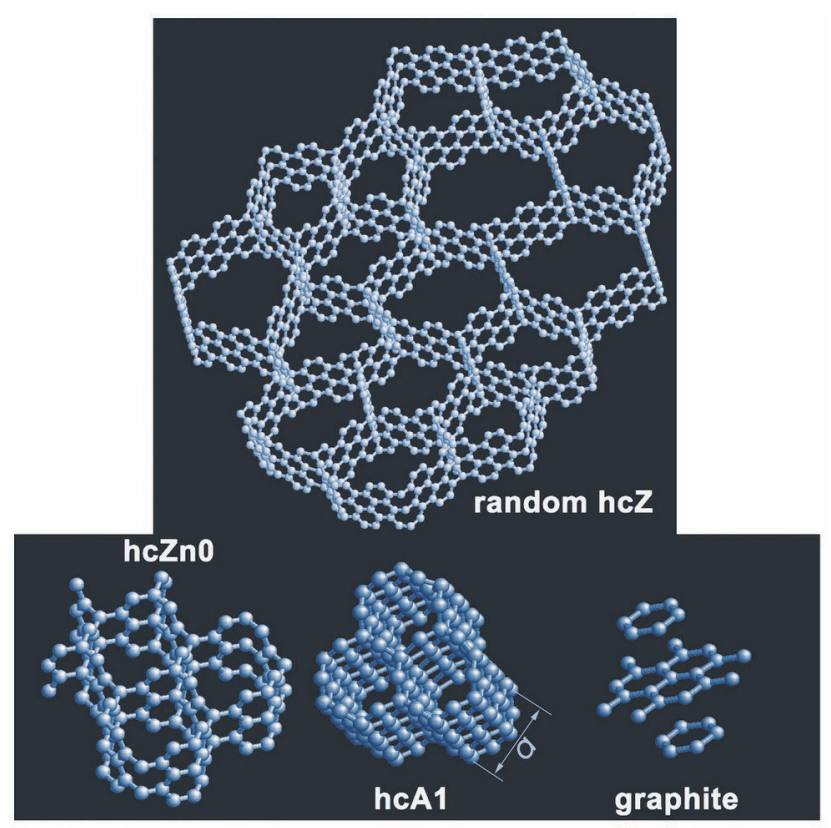

Fig. 2. (Color online) The carbon structures corresponding to the best-fit analysis of experimental diffraction intensities: the random honeycomb of a zigzag type (hcZ) found previously in [14], a fragment of a regular densest honeycomb structure also of a zigzag type (hcZn0) for $n=0$ in $a_{0}$ (see the text), the densest honeycomb structure of an armchair type [20] first identified in our experiment (hcA1, $a$ is a parameter of the hexagonal honeycomb lattice) and a small graphitic fragment (Gr), whose contribution to the total diffraction intensity is $\sim 5 \%$ (see Fig. 3 ).
$r_{N N}=1.44 \AA$ is the nearest neighbor distance in a graphitic layer and $n$ is an integer. The total classification of the armchair honeycombs is presented in [20].

In Fig. 2 we show the structures, which were found to be the best candidates for the analysis of the experimental diffractogram presented in Fig. 3(a) by means of the fitting procedure described in the previous section. Usually three broadened peaks can be identified in such diffractograms. If we worked with glassy graphite their positions would coincide with vertical lines in Fig. 3(a). The graphitic peaks (100) and (110) correspond to relevant hexagonal spacing inside the graphene plane while the peak (002) — to the distance between graphitic layers. Therefore two peak positions (100) and (110) may also be expected in the honeycombs as well since walls of these structures are essentially graphene ribbons. But no distinct peak in the graphitic position (002) is visible. Instead at the noticeably smaller angle we can see the well identified peak, which is close to the (100) position of the hexagonal honeycomb lattice of an armchair type (hcA1) although not exactly. The other honeycombs presented in Fig. 2 also contribute to this peak at a little smaller angles (or $S$ ).

The total distribution of all contributing structures over cell sizes $(a)$ is shown in Fig. 3(b). For graphite whose
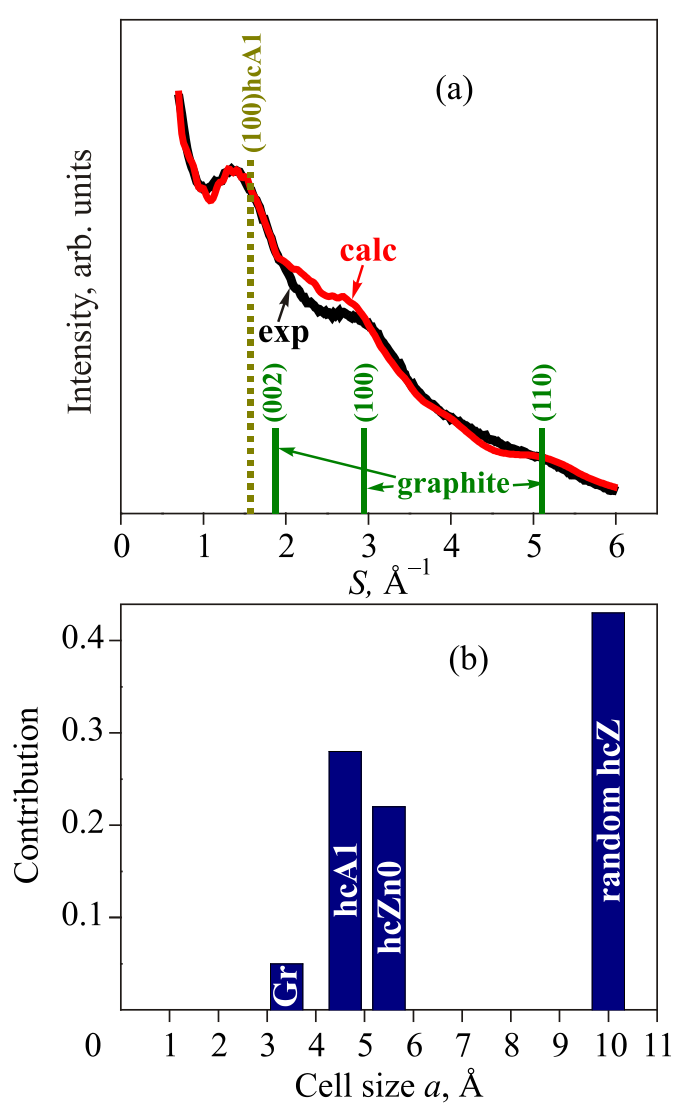

Fig. 3. (Color online) The experimental and best-fit calculated diffraction intensities for the carbon films specifically prepared as described in the text to form the cellular structures of a honeycomb type (a). Relative contributions of different structures found from best-fit analysis and presented in Fig. 2(b). 


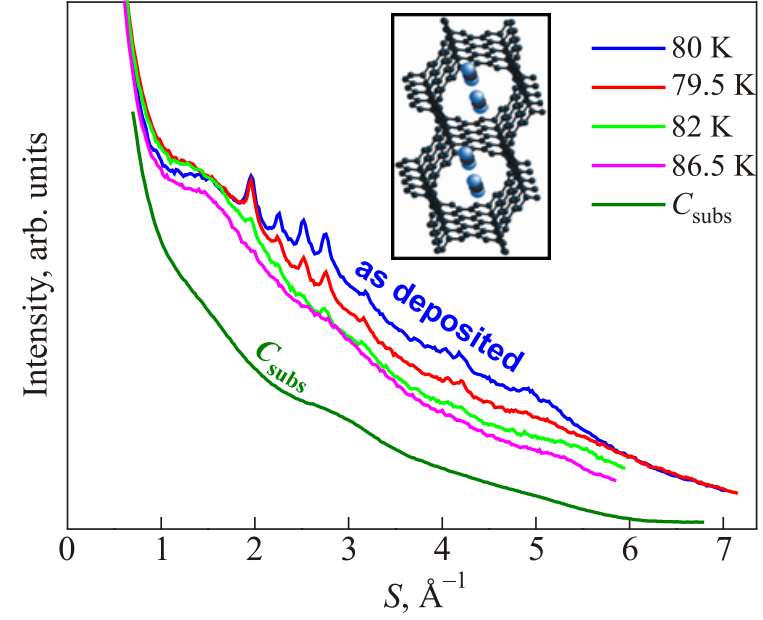

Fig. 4. (Color online) The diffraction intensities recorded during deposition of carbon dioxide at $\sim 80 \mathrm{~K}$, which indicate fast absorption of the gas during condensation, and angle intensity dependences (or on $S$ ) for formed composites as compared with a carbon substrate at further heating.

contribution was found $\sim 5 \%$ we used here the interplanar distance of $3.43 \AA$. It is obvious that the honeycomb structures are absolutely dominant in our study. In this work we first identified the densest honeycomb structure of an armchair type (hcA1) shown in Fig. 2.

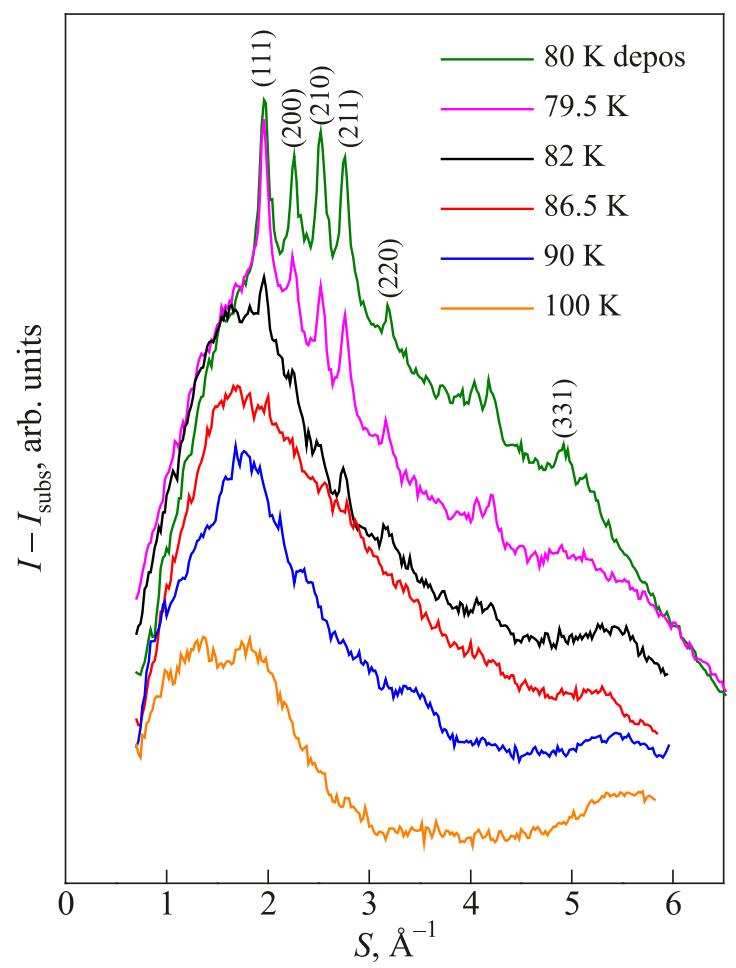

\section{The absorption-desorption effect}

As it was described above intensive absorption of carbon dioxide occurs when molecules are deposited on carbon films prepared from vacuum sublimated graphite below the sublimation temperature $T_{\text {subl }}$. There were analyzed two options. When we deposited gases well below $T_{\text {subl }}$ first a good quality polycrystalline films with the intrinsic molecular dynamics formed $[14,18,28]$. After gradual heating and further keeping condensates a few degrees lower $T_{\text {subl }}$ $\mathrm{CO}_{2}$ molecules were absorbed by the carbon supporting films owing to fast diffusion and stronger interaction with pore walls as compared with interaction between molecules themselves. In this work we condense carbon dioxide at $\sim 80 \mathrm{~K}$, i.e., only a few degrees lower $T_{\text {subl, }}$, and intensive absorption occurs already during deposition. Polycrystalline peaks, which are initially well visible, fast disappear (Fig. 4).

We analyze further evolution of formed composites, i.e., $\mathrm{CO}_{2}$ molecules absorbed in carbon honeycomb matrices, under heating up to $\sim 230 \mathrm{~K}$ considering a difference between experimental intensities $I$ from composites and $I_{\text {subs }}$ from a carbon substrate (Fig. 5). The absorbed gases can be identified owing to the wide but well defined peak attributed to molecules captured in the carbon honeycomb matrices. This means that molecules are not randomly distributed in carbon matrix channels but form some kind of short range order. The important question is how atoms

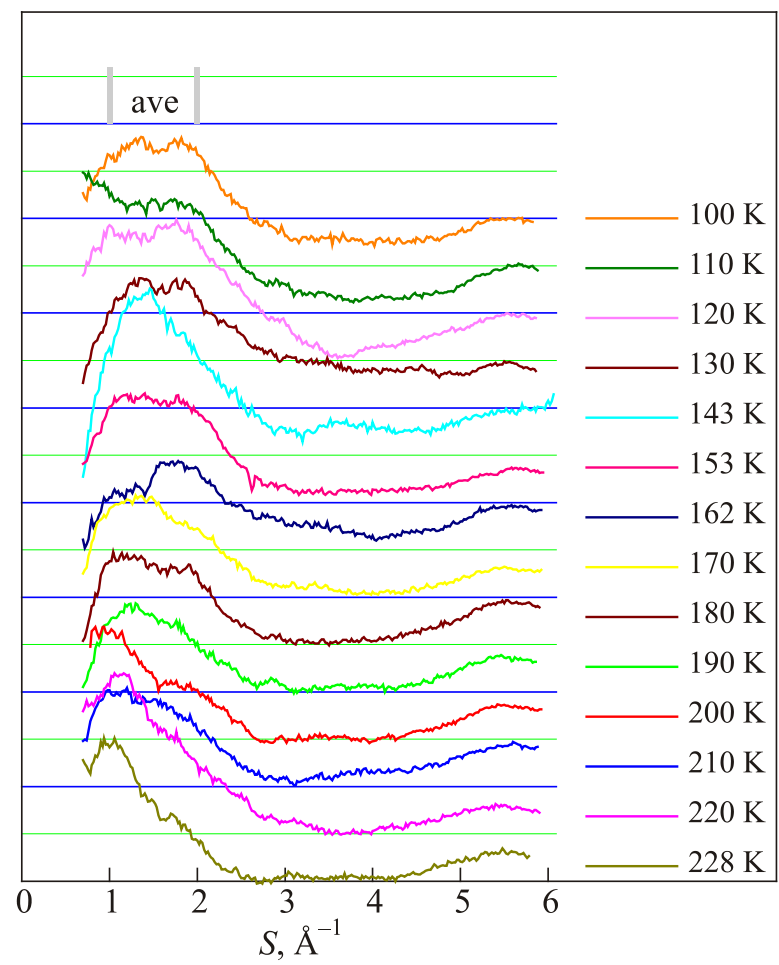

Fig. 5. (Color online) An access of experimental diffraction intensities from composites formed by carbon dioxide absorbed in carbon honeycomb matrices during deposition closely to $T_{\text {subl }}$ of $\mathrm{CO}_{2}$ in vacuum as compared with intensities from a carbon substrate. On the right diffractograms are shifted along vertical to make details visible. A wide but well defined peak is attributed to molecules with short range order captured in the carbon honeycomb matrices and is kept up to $\sim 230 \mathrm{~K}$ that is about three times higher as compared with $T_{\text {subl }} \sim 86 \mathrm{~K}$. 
and molecules can be distributed inside porous carbon matrices. The exact answers can be obtained by direct modeling such composites applying, e.g., the Monte Carlo method $[29,30]$.

During deposition along with the absorbate broad peak we can see also distinct peaks from polycrystalline $\mathrm{CO}_{2}$ films. But these polycrystalline peaks fast disappear already at $82 \mathrm{~K}$. The broad absorbate peak evolves with temperature changing its form and height. It is most plausible that this peak is a superposition of two or more contributors. Most diffractograms exhibit this peak splitting into at least two positions. One is close to the (111) diffraction peak of polycrystalline $\mathrm{CO}_{2}$ at $S \sim 1.95 \AA^{-1}$ that imply local molecule arrangements similar to those in crystalline carbon dioxide. The other peak is located at smaller $S$ and mutual molecule positions and orientations corresponding to this peak require more detailed modeling.

To analyze the temperature behavior of composites we average intensities shown in Fig. 5 over the main broad peak in the $S$ interval 1-2 $\AA^{-1}$ (marked by "ave") and consider such a signal as a function of temperature (Fig. 6). We see a distinct decay of this signal at elevated temperatures from its highest value at the deposition temperature to about three times weaker intensity at $T \sim 230 \mathrm{~K}$.

We can distinguish at least two stages in the temperature dependence shown in Fig. 6. One stretches from the deposition temperature up to $\sim 140 \mathrm{~K}$ while the other one exhibits another decay between 140 and $\sim 230 \mathrm{~K}$. It is natural to suppose that inside cells in carbon honeycombs $\mathrm{CO}_{2}$ molecules can interact with pore walls stronger or weaker depending on channel configurations and sizes. In the less dense random honeycomb structure the $\mathrm{CO}_{2}$ absorbate cannot be kept at sufficiently high temperatures while in the denser structures hcAl and hcZn0 bonds with pore walls apparently are much stronger.

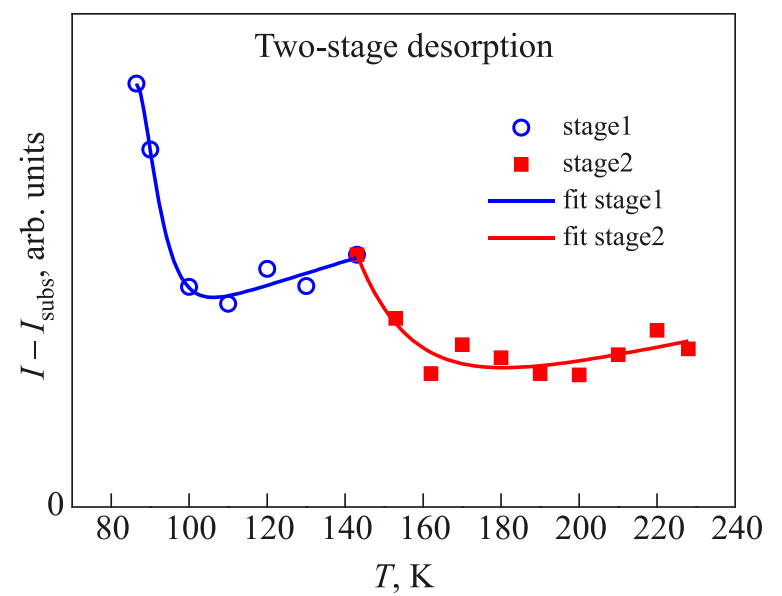

Fig. 6. (Color online) Temperature dependence of the diffraction intensity access with respect to a signal from a carbon substrate that exhibits two - stage character of $\mathrm{CO}_{2}$ desorption in a wide temperature range up to $T$ values about three times higher as compared with the sublimation point of polycrystalline carbon dioxide in our vacuum conditions.
For fitting the experimental data we use the exponential decay function $f(T)=a+b_{1} \exp \left(-\left(T-T_{0}\right) / c\right)+b_{2} T$ for reduction of diffracted intensities ( $I-I_{\text {subs }}$ in Fig. 6) with temperature $T$ associated with the molecule release from larger or thinner channels in the first and second stages respectively ( $a, b_{1}, b_{2}, c$ and $T_{0}$ are fitting parameters). In both stages we observe a slight "linear" growth of intensities that can be ascribed to relaxation of structures formed in carbon nanochannels towards to their better arrangements.

\section{Conclusions}

Varying the preparation conditions under sublimation of carbon patches from the thinned graphitic rods heated by the electric current we have found that at the parameters corresponding to the faster deposition and therefore to the denser structure formations honeycomb structures are still absolutely dominant. In these regimes we could also obtain the armchair type honeycomb structure (hcA1) with thinnest possible for honeycomb channels, which was earlier not identified.

In this work we analyze the behavior of composites formed from the carbon honeycomb structure filled with carbon dioxide at elevated temperatures and have found that complete desorption of carbon dioxide captured in the carbon honeycomb matrix does not occur even at the temperatures about three times higher as compared with the sublimation point of $\mathrm{CO}_{2}$ in a polycrystalline state in our vacuum conditions.

The desorption observed as a temperature function has distinct two-stage character that is attributed to differently bonded $\mathrm{CO}_{2}$ molecules with honeycomb walls depending on channel configurations and sizes. Apparently in the thinner channels of the densest honeycomb of an armchair type (hcA1) and in a densest structure of a zigzag type (hcZn0) $\mathrm{CO}_{2}$ molecules are kept by walls much stronger as compared with their interactions with walls in random structures of a zigzag type.

\section{Acknowledgements}

BK acknowledges support by the French National Research Agency (ANR), grant number ANR-14-CE05-0 009 HYSTOR.

1. H.W. Kroto, J.R. Heath, S.C. O'Brien, R.F. Curl, and R.E. Smalley, Nature 318, 162 (1985).

2. S. Iijima, Nature 354, 56 (1991).

3. A. Thess, R. Lee, P. Nikolaev, H. Dai, P. Petit, J. Robert, C. $\mathrm{Xu}$, Y. Lee, S. Kim, A.G. Rinzler, D. Colbert, G.E. Scuseria, D. Tománek, J.E. Fischer, and R.E. Smalley, Science 273, 483 (1996).

4. P. Utko, R. Ferone, I.V. Krive, R.I. Shekhter, M. Jonson, M. Monthioux, L. Noé, and J. Nygård, Nature Commun. 1, 37 (2010).

5. T. Lenosky, X. Gonze, M. Teter, and V. Elser, Nature 355, 333 (1992). 
6. S.J. Townsend, T.J. Lenosky, D.A. Muller, C.S. Nichols, and V. Elser, Phys. Rev. Lett. 69, 921 (1992).

7. E. Barborini, P. Piseri, and P. Milani, Appl. Phys. Lett. 81, 3359 (2002).

8. A. Milani, M. Tommasini, V. Russo, A.L. Bassi, A. Lucotti, F. Cataldo, and C.S. Casari, Beilstein J. Nanotechnol. 6, 480 (2015).

9. K.S. Novoselov, A.K. Geim, S.V. Morozov, D. Jiang, Y. Zhang, S.V. Dubonos, I.V. Grigorieva, and A.A. Firsov, Science 306, 666 (2004).

10. F. Ding, Yu Lin, P.O. Krasnov, and B.I. Yakobson, J. Chem. Phys. 127, 164703 (2007).

11. A.K. Singh, J. Lu, R.S. Aga, and B.I. Yakobson, J. Phys. Chem. C 115, 2476 (2011).

12. L. Firlej, B. Kuchta, A. Lazarewicz, and P. Pfeifer, Carbon 53, 208 (2013).

13. B. Kuchta, L. Firlej, A. Mohammadhosseini, P. Boulet, M. Beckner, J. Romanos, and P. Pfeifer, J. Amer. Chem. Soc. 134, 15130 (2012).

14. N.V. Krainyukova and E.N. Zubarev, Phys. Rev. Lett. 116, 055501 (2016).

15. N.V. Krainyukova, Fiz. Nizk. Temp. 35, 385 (2009) [Low Temp. Phys. 35, 294 (2009)].

16. A.V. Dolbin, V.B. Esel'son, V.G. Gavrilko, V.G. Manzhelii, N.A. Vinnikov, I.I. Yaskovets, I.Yu. Uvarova, N.A. Tripachko, and B.A. Danilchenko, Fiz. Nizk. Temp. 39, 790 (2013) [Low Temp. Phys. 39, 610 (2013)].

17. A.V. Dolbin, V.B. Esel'son, V.G. Gavrilko, V.G. Manzhelii, N.A. Vinnikov, R.M. Basnukaeva, I.I. Yaskovets, I.Yu. Uvarova, and B.A. Danilchenko, Fiz. Nizk. Temp. 40, 317 (2014) [Low Temp. Phys. 40, 246 (2014)].

18. N.V. Krainyukova, J. Low Temp. Phys. 187, 90 (2017).

19. T. Kawai, S. Okada, Y. Miyamoto, and A. Oshiyama, Phys. Rev. B 72, 035428 (2005).

20. Z. Zhang, A. Kutana, Ya. Yang, N.V. Krainyukova, E. Penev, and B.I. Yakobson, Carbon 113, 26 (2017).

21. A. Kuc and G. Seifert, Phys. Rev. B 74, 214104 (2006).

22. A. Martínez-Mesa, L. Zhechkov, S.N. Yurchenko, T. Heine, G. Seifert, and J. Rubayo-Soneira, J. Phys. Chem. C 116, 19543 (2012).

23. Z. Zhu and D. Tománek, Phys.Rev. Lett. 109, 135501 (2012).

24. Z. Zhu, Z.G. Fthenakis, J. Guan, and D. Tománek, Phys. Rev. Lett. 112, 026803 (2014).

25. N.V. Krainyukova and B.W. van de Waal, Thin Solid Films 459, 169 (2004).

26. B.E. Warren, X-Ray Diffraction, Addison-Wesley, Reading, MA (1969).

27. V. Kiryukhin, E.P. Bernard, V.V. Khmelenko, R.E. Boltnev, N.V. Krainyukova, and D.M. Lee, Phys. Rev. Lett. 98, 195506 (2007).

28. N. Krainyukova and B. Kuchta, J. Low Temp. Phys. 187, 148 (2017).

29. R. Etters, E. Flenner, B. Kuchta, L. Firlej, and W. Przydrozny, J. Low Temp. Phys. 122, 121 (2001).

30. L. Firlej, B. Kuchta, R. Etters, W. Przydrozny, and E. Flenner, J. Low Temp. Phys. 122, 171 (2001).
Абсорбція-десорбція вуглекислого газу у вуглецевих сотах при підвищених температурах

\section{Н.В. Крайнюкова, Ю.С. Богданов, Б. Кухта}

Нещодавно синтезований вуглецевий стільниковий алотроп має численні потенційні застосування, зокрема для зберігання газів всередині вуглецевих матриць. Таку вуглецеву форму було експериментально досліджено в іiі більш щільній формі, щоб оцінити верхню границю температури, при якій газ зберігається всередині пористої структури. Поряд з раніше запропонованими випадковими стільниками зигзагоподібного типу виявлено найбільш щільну структуру типу armchair. Механізм поглинання-десорбція діоксиду вуглецю, що досліджено за допомогою дифракції електронів високої енергії при низьких температурах, показав двохстадійний характер десорбції, який спостерігається при підвищенні температури. Цей ефект пов'язаний з більш слабким або більш сильним зв'язуванням молекул зі стінками пор в залежності від конкретної конфігурації каналів різного розміру. Виявлено, що повна десорбція $\mathrm{CO}_{2}$ не відбувається навіть при температурах приблизно в три рази вищих у порівнянні з точкою сублімації вуглекислого газу в наших вакуумних умовах.

Ключові слова: дифракція високоенергетичних електронів, газова абсорбція, вуглецеві стільники.

\section{Абсорбция-десорбция углекислого газа в углеродных сотах при повышенных температурах}

\section{Н.В. Крайнюкова, Ю.С. Богданов, Б. Кухта}

Недавно синтезированный углеродный сотовый аллотроп имеет множество потенциальных применений, в частности для хранения газов внутри углеродных матриц. Такая углеродная форма была экспериментально исследована в ее более плотной форме, чтобы оценить верхний предел температуры, при которой газ сохраняется внутри ячеистой структуры. Наряду с ранее предложенными случайными сотами зигзагообразного типа обнаружена самая плотная структура типа armchair. Механизм поглощение-десорбция диоксида углерода, изучаемый с помощью дифракции электронов высокой энергии при низких температурах, показал двухстадийный характер наблюдаемой десорбции при повышении температуры. Этот эффект связан с более слабым или более сильным связыванием молекул со стенками пор в зависимости от конкретной конфигурации каналов разного размера. Обнаружено, что полная десорбция $\mathrm{CO}_{2}$ не происходит даже при температурах примерно в три раза более высоких по сравнению с точкой сублимации углекислого газа в наших вакуумных условиях.

Ключевые слова: дифракция высокоэнергетичных электронов, газовая абсорбция, углеродные соты. 